rompay Klára tiszteletére. [ELTE BTK] Magyar Nyelvtörténeti, Szociolingvisztikai, Dialektológiai Tanszék, Budapest, 185-195.

LÜKÖ GÁBOR 1936/2002. A moldvai csángók. A csángók kapcsolata az erdélyi magyarsággal. Lükő Gábor müvei 2. Táton Kiadó, Budapest.

JUHÁSZ DEZSŐ - TERBE ERIKA

ELTE Eötvös Loránd Tudományegyetem

\title{
LEVÉLSZEKRÉNY
}

Fábián István írja. Aktívabb akadémiai fellépés az áltudományok ellen. - A tudomány eredményeinek hiteles és közérthető közvetítésére hívja fel a kutatói közösséget a Magyar Tudományos Akadémia Közgyülése által elfogadott határozat. Az MTA legfőbb döntéshozó testülete egyúttal üdvözölte a tudomany.hu címen elérhető új honlapot, amely a tudományosnak tünő, de hamis elméletekkel szemben a tudományosan megalapozott, hiteles ismeretek közvetítőjeként járulhat hozzá az akadémiai célkitüzés sikeréhez.

A tudományba vetett bizalom megrendülése, az alternatívként megjelölt, ám a tudomány alapelveinek nem megfelelő, tudománytalannak tekinthető megnyilatkozások terjedése világjelenség. A tudomány alapelveinek támadása, az áltanok, a tudományosnak, meggyőzőnek tűnő, de hamis elméletek terjedése Magyarországon is egyre erősödik. A Magyar Tudományos Akadémia - mint a tudományért felelős, legnagyobb közbizalmat élvezö köztestület - az eddigieknél is erőteljesebb és aktívabb szerepet kíván vállalni ennek a világ és Magyarország jövőjét egyaránt hátrányosan befolyásoló jelenségnek a visszaszorításában.

A Magyar Tudományos Akadémia Közgyülése által elfogadott határozat ezért felhívja az MTA köztestületének valamennyi tagját a tudomány alapelveinek aktív, következetes képviseletére a kutatói közösségek, a nagyközönség, a média, a politikai döntéshozók és a szakpolitikusok számára készülő közléseiben és javaslataiban, továbbá a tudományos érvelés, szükség esetén a közös fellépés erősítésére a megalapozatlan tanokkal szemben.

A határozat továbbá felhívja Magyarország valamennyi kutatói közösségét, hogy a tudomány közvetítése a társadalom felé hiteles és közérthető legyen, és a tudomány természetének, céljainak és módszereinek mély, aktív ismeretén és használatán alapuljon.

A Közgyülés Magyarország valamennyi oktatójához és kutatójához fordulva, annak közvetítésére szólít fel, hogy a tudomány feladata a mélyebb megértés, a tudományos felismerések közlése, elfogadtatása és alkalmazása, valamint a tudományosan megalapozott, hiteles elméletek képviselete. „A tudomány sosem zárt, végleges rendszer; az azonos időben versengő felfogások létezése a tudomány sajátossága egy történetileg érvényes módszertani egyetértés keretei között. Fontos figyelembe venni az egyes tudományterületeken alkalmazott érvelési eljárások sajátosságait, és el kell kerülni a tudós saját szakterületének megfontolatlan átlépését" - olvasható a határozatban.

A Közgyülés felkéri az MTA minden tagját és köztestületi tagját, hogy vállaljon aktív szerepet, és lépjen fel a tudomány alapelveitől idegen, annak ethoszát és etikáját sértő eszmerendszerekkel szemben. 
Elvárja, hogy minden közpénzből finanszírozott kutatóintézmény müködése nyilvános legyen, a tudomány módszereinek és etikájának megfelelően folyjék, és érvényesüljön a kutatások független értékelésére támaszkodó minőségbiztosítás.

Végül üdvözli a tudomany.hu honlap megalapítását, amely a fenti célokat szolgálja, és felkéri a tudományos közösséget, hogy aktívan járuljon hozzá küldetésének sikeréhez.

\section{Számunk szerzői}

DR. BALÁZS GÉZA, Eötvös Loránd Tudományegyetem, Magyar Nyelvtudományi és Finnugor Intézet, Mai Magyar Nyelvi Tanszék, 1088 Budapest, Múzeum krt. 4/A, balazs.geza@gmail.com - DR. BARANYINÉ KÓCZY JUDIT, Széchenyi István Egyetem, Nemzetközi Tanulmányok és Kommunikáció Tanszék, 9022 Győr, Liszt Ferenc u. 42. baranyine.koczy.judit@sze.hu - DR. BENCzEs RÉKA, Budapesti Corvinus Egyetem, Magatartástudományi és Kommunikációelméleti Intézet, 1093 Budapest, Közraktár utca 4-6., reka.benczes@uni-corvinus.hu - DR. BENYOVSZKY KRISZTIÁN, Nyitrai Konstantin Filozófus Egyetem, Magyar Nyelv- és Irodalomtudományi Intézet, Dražovská cesta 4, 949 74 Nitra, Szlovákia, kbenyovszky@ukf.sk - DR. FÁBIÁn IsTVÁN, Debreceni Egyetem, Kémiai Intézet, Szervetlen és Analitikai Kémiai Tanszék, 4032 Debrecen, Egyetem tér 1., ifabian@science.unideb.hu - DR. ForGÁcs TAMÁs, Szegedi Tudományegyetem, Magyar Nyelvi és Irodalmi Intézet, Magyar Nyelvészeti Tanszék, 6722 Szeged, Egyetem u. 2., forgacs@hung.u-szeged.hu - DR. GAZDAG VILMOS, II. Rákóczi Ferenc Kárpátaljai Magyar Főiskola, Magyar Tanszéki Csoport, 90202 Beregszász, Kossuth tér 6. Ukrajna, gazdagvilmos@gmail.com - DR. Hegedüs AtTiLA, Pázmány Péter Katolikus Egyetem, Magyar Nyelv- és Irodalomtudományi Intézet, Magyar Nyelvészeti Tanszék, 2081 Piliscsaba, Egyetem u. 1., hegedus@btk.ppke.hu - DR. JuHÁsz DEzsŐ, Eötvös Loránd Tudományegyetem, Magyar Nyelvtudományi és Finnugor Intézet, Magyar Nyelvtörténeti, Szociolingvisztikai, Dialektológiai Tanszék, 1088 Budapest, Múzeum krt. 4/A, juhasz. dezso@btk.elte.hu - DR. KARA GYÖRGY, Indiana University, Department of Central Eurasian Studies, 355 North Jordan Ave. Bloomington, IN 47405-1105, gkara@indiana.edu PÁJI GRÉTA, Eötvös Loránd Tudományegyetem, Nyelvtudományi Doktori Iskola, 1088 Budapest, Múzeum krt. 4/A, gretapalyi@gmail.com - Dr. PrEsInszKY KÁROLY, Nyitrai Konstantin Filozófus Egyetem, Közép-Európai Tanulmányok Kara, Magyar Nyelv- és Irodalomtudományi Intézet, 94974 Nitra, Dražovská 4, Slovenská Republika, kpresinszky@ ukf.sk - SIKLÓSI BEÁTA, Eötvös Loránd Tudományegyetem, Nyelvtudományi Doktori Iskola, 1088 Budapest, Múzeum krt. 4/A, bsiklosi@gmail.com - Dr. TERBE ERIKA, Eötvös Loránd Tudományegyetem, Magyar Nyelvtudományi és Finnugor Intézet, Magyar Nyelvtörténeti, Szociolingvisztikai, Dialektológiai Tanszék, 1088 Budapest, Múzeum krt. 4/A, terbe.erika@btk.elte.hu - DR. TVERDOTA GYÖRGY - DR. VÖRÖS OTTÓ. 